\title{
PENGEMBANGAN MEDIA KARTU DOMINO PADA PEMBELAJARAN IPA DENGAN TOPIK HEWAN DAN TUMBUHAN DI LINGKUNGAN RUMAHKU UNTUK SISWA KELAS IV SD
}

\author{
N.L.G. Wiratni ${ }^{1}$, I M. Ardana $^{2}$, I.B.P. Mardana ${ }^{3}$ \\ ${ }^{123}$ Program Studi Pendidikan Dasar \\ Universitas Pendidikan Ganesha \\ Singaraja, Indonesia \\ e-mail: wiratni@undiksha.ac.id ${ }^{1}$, ardanaimade@undiksha.ac.id ${ }^{2}$, \\ putu.mardana@undiksha.ac.id ${ }^{3}$
}

\begin{abstract}
Abstrak
Penelitian ini bertujuan mengetahui: (1) validitas hasil pengembangan media kartu domino (2) untuk kepraktisan penggunaan media kartu domino, dan (3) untuk efektivitas media kartu domino dalam meningkatkan hasil belajar siswa. Jenis penelitian ini adalah penelitian pengembangan dengan menggunakan model ADDIE (analysis, design, development, implementation, evaluation). Metode pengumpulan data yang digunakan pada penelitian ini yaitu dengan wawancara, kuesioner, tes, dan pencatatan dokumen. Instrumen pengumpulan data dalam penelitian ini data validitas dikumpulkan dengan kuesioner, data kepraktisan dikumpulkan dengan kuesioner dan data efektivitas dikumpulkan dengan tes hasil belajar. Hasil penelitian menunjukkan bahwa media kartu domino dinyatakan valid oleh ahli isi mata pelajaran dengan kriteria sangat baik (92\%), ahli media pembelajaran dengan kriteria sangat baik $(90 \%)$, uji coba kelompok kecil dengan kriteria sangat baik $(92 \%)$, dan uji coba lapangan dengan kriteria sangat baik (93\%). Kepraktisan media kartu domino yang diperoleh dari skor rata-rata respon guru sebesar 4,53 dengan kategori sangat tinggi dan skor rata-rata dari respon siswa sebesar 4,56 dengan kategori sangat tinggi. Hasil uji efektivitas menunjukkan nilai rata-rata pretest $53,52<$ hasil rata-rata posttest 83,69 dan dapat dikatakan bahwa media kartu domino efektif.
\end{abstract}

Kata kunci: Keefektivan; Kepraktisan; Media Kartu Domino; Pembelajaran IPA; Validitas

\begin{abstract}
This study aims to determine: (1) the validity of the results of developing domino card media (2) for the practicality of using domino card media, and (3) for the effectiveness of domino card media in improving student learning outcomes. This type of research is development research using the ADDIE model (analysis, design, development, implementation, evaluation). The data collection methods used in this study were interviews, questionnaires, tests, and document recording. The data collection instruments in this study were data validity was collected by questionnaire, practicality data was collected by questionnaire and effectiveness data was collected by learning outcomes test. The results showed that domino card media was declared valid by subject content experts with very good criteria (92\%), learning media experts with very good criteria (90\%), small group trials with very good criteria (92\%), and field trials with very good criteria (93\%). The practicality of domino card media obtained from the average teacher response score of 4.53 with very high and the average score of student responses is 4.56 with a very high category. The results of the effectiveness test shows the average pretest value of $53.52<$ the average posttest result of 83.69 and it can be said that the domino card media is effective.
\end{abstract}

Keywords : Effectiveness; Practicality; Domino Card Media; Science Learning; Validity 


\section{PENDAHULUAN}

Setiap warga negara Indonesia wajib mendapatkan pendidikan yang layak. Pendidikan adalah hal yang sangat penting bagi kehidupan manusia, dengan adanya pendidikan manusia dapat mengembangkan potensi-potensi yang ada di dalam dirinya. Pendidikan adalah akar dari peradaban bangsa yang harus dikembangkan dan ditingkatkan hingga nantinya dapat tercapai cita-cita bangsa Indonesia seperti yang tertuang dalam Undang-Undang Republik Indonesia Nomor 20 Tahun 2003 Tentang Sistem Pendidikan Nasional menyatakan, Pendidikan adalah usaha sadar dan terencana untuk mewujudkan suasana belajar dan proses pembelajaran agar peserta didik secara aktif mengembangkan potensi dirinya untuk memiliki kekuatan spiritual keagamaan, pengendalian diri, kepribadian, kecerdasan, ahlak mulia, serta keterampilan yang diperlukan dirinya, masyarakat, bangsa, dan negara.

Mengingat pentingnya pendidikan bagi kehidupan manusia, pemerintah Indonesia telah berusaha meningkatkan kualitas pendidikan. Berbagai upaya dilakukan dalam rangka peningkatan kualitas pendidikan, upaya yang dilakukan hampir mencakup semua komponen pendidikan seperti perubahan kurikulum, pendekatan proses belajar mengajar, peningkatan kualitas guru, penyempurnaan sistem pembelajaran, dan menyiapkan sarana dan prasarana sekolah. Upaya peningkataan kualitas tersebut dilakukan untuk menyediakan pendidikan yang bermutu bagi rakyatnya di berbagai jenjang pendidikan. Pendidikan yang bermutu akan mampu menghasilkan manusia dengan pribadi yang integral (integrated personality) yaitu mereka yang mampu mengintegrasikan iman, ilmu, dan amal (Sudradjat, 2005).

Mutu pendidikan merupakan salah satu faktor yang menentukan (SDM) suatu bangsa. Untuk itu perlu dilakukan pembaharuan dalam bidang pendidikan dari waktu ke waktu karena pendidikan selalu mengalami perubahan. Oleh karena itu inovasi pendidikan sangat penting untuk dilakukan. Inovasi pendidikan merupakan pemikiran cemerlang dengan ciri hal baru yang berupa produk atau hasil mengolah nalar dengan maksud untuk mengatasi permasalahan dalam sektor pendidikan (Kusnadi, 2017).

Pembelajaran yang berkualitas harus dilaksanakan dalam semua mata pelajaran termasuk mata pelajaran IPA. Menurut (Permendiknas, 2006), IPA merupakan salah satu mata pelajaran pokok dalam kurikulum pendidikan di Indonesia, termasuk pada jenjang sekolah dasar. Proses pembelajaran IPA menekankan pada pemberian pengalaman langsung untuk mengembangkan kompetensi agar menjelajahi dan memahami alam sekitar secara ilmiah. Menurut (Sari, 2017) menyatakan pendidikan IPA di sekolah dasar diharapkan dapat menjadi wahana bagi siswa untuk mempelajari dirinya sendiri dan alam semesta. Sehingga belajar IPA menjadi sangat menarik, namun sepanjang perjalanan pendidikan sampai sekarang pemahaman siswa tentang konsep-konsep IPA belum seperti yang diharapkan. Model pembelajaran yang digunkan masih konvensional dan kurangnya media pembelajaran.

Kualitas pendidikan di Indonesia nyatanya masih tertinggal jauh dibandingkan negara-negara yang lainnya. Salah satu indikator rendahnya kualitas pembelajaran di Indonesia dapat dilihat dari hasil data dari Programme for International Student Assesment (PISA) pada 2018 yang dirilis Desember 2019. Indonesia mengalami penurunan skor dalam kompetensi IPA dari 403 pada tahun 2015 menjadi 396 pada tahun 2018. Indonesia hanya mampu menempati peringkat 72 dengan total 396 poin di bidang IPA dari 77 negara yang dievaluasi. Ditinjau dari skor yang diperoleh Indonesia berdasarkan data PISA 2018, dibandingkan dengan standar kriteria penilaian oleh OECD (Organization for Economic Co-operation and Development) dalam kopentensi IPA hanya 40 persen 
siswa yang mampu sampai kemahiran tingkat dua atau lebih sedangkan rata-rata OECD mencapai 78 persen (Syahrul, 2019). Hasil wawancara, observasi, dan pencatatan dokumen di SD No. 2 Mengwitani yang dilakukan pada hari Rabu, 20 Januari 2021 dengan mewawancarai guru kelas IV diperoleh informasi mengenai beberapa permasalahan pada kegiatan belajar mengajar yaitu (1) Siswa menganggap bahwa mata pelajaran IPA merupakan mata pelajaran yang sulit, membosankan, dan tidak menarik. (2) Guru sudah menggunakan media pembelajaran berupa gambar, namun media pembelajaran yang digunakan tidak sesuai dengan karakteristik siswa. Siswa kelas IV SD senang dan sangat bersemangat jika belajar sambil bermain menggunakan media visual dengan gambar-gambar yang menarik. (3) Pembelajaran hanya berdasarkan buku pegangan siswa sehingga kurang kreatif dan membuat siswa kuranng tertarik terhadap pembelajaran. (4) Siswa kurang aktif dan antusias dalam mengikuti pembelajaran, dibuktikan dari sedikitnya siswa yang mengacungkan tangan untuk menjawab pertanyaan yang diberikan guru sesuai dengan materi yang telah disampaikan dan sebagian siswa terlihat kurang memperhatikan penjelasan dari guru saat pembelajaran berlangsung. Ada yang bermain dan berbicara dengan teman, beraktivitas sendiri, kurang konsentrasi dengan penjelasan guru. (5) Siswa juga mengalami kesulitan pada pemahaman materi pelajaran topik hewan dan tumbuhan di lingkungan rumahku. Siswa cenderung menghafal dan kurang memiliki gambaran secara langsung mengenai hewan dan tumbuhan. Permasalahan tersebut mengakibatkan hasil belajar IPA yang dicapai siswa kelas IV masih kurang memenuhi Kriteria Ketuntasan Minimal (KKM) yang ditetapkan dengan angka 67.

Berdasarkan hasil wawancara yang telah dilakukan dapat disimpulkan bahwa peran siswa dalam pembelajaran hanyalah mendengarkan dan memperhatikan penjelasan dari guru. Sumber belajar yang digunakan oleh guru hanyalah buku pegangan siswa, maka dibutuhkan suatu media pembelajaran yang menarik yang dapat membantu siswa agar mudah dalam memahami materi serta membantu siswa lebih aktif ketika mengikuti pembelajaran dan dapat meningkatkan hasil belajar IPA siswa kelas IV SD. Menurut (Istiqomah, F., \& Widiyatmoka, 2016) pembelajaran IPA dengan menggunakan media pembelajaran melalui permainan dan diskusi kelompok dapat meningkatkan kemampuan berpikir kognitif siswa dan hasil belajar siswa.

Menurut (Ibdal, 2015) secara teori anak usia SD berada pada tahap oprasional konkret yang pada saat belajar memerlukan objek yang bersifat konkret. Mereka akan kesulitan apabila tanpa bantuan bendabenda yang mampu merepresentasikan hal yang dimaksud. Selanjutnya, (Prastowo, 2013) menyatakan siswa usia SD ketika belajar mempunyai tiga karakteristik yang menonjol, yaitu konkret, integratif dan hierarkis. Konkret berarti pada proses pembelajaran siswa dihadapkan dengan keadaan sebenarnya dan keadaan yang alami, sehingga lebih nyata, faktual, bermakna, dan kebenarannya dapat dipertanggung jawabkan. Integratif berarti memandang sesuatu yang dipelajari sebagai suatu keutuhan dan terpadu. Siswa usia sekolah dasar belum mampu memilahmilah konsep dari berbagai bidang disiplin ilmu. Hierarkis berarti berkembang secara bertahap mulai dari hal-hal yang sederhana hingga kompleks.

Untuk mengatasi permasalahan dan penyebab yang timbul dalam pembelajaran IPA, maka perlu mengembangkan media pembelajaran. Media adalah salah satu komponen penentu dalam pembelajaran, media sebagai alat penghubung untuk menyampaikan sesuatu yang sengaja direncanakan oleh guru sebagai persiapan dalam menjelaskan materi sehingga memungkinkan para siswa untuk berpartisipasi secara langsung demi tercapainya tujuan dari pembelajaran. 
(Mulyawati \& Kowiyah, 2018). Media pembelajaran sangat berperan penting dalam aktivitas pembelajaran karena media pembelajaran dapat memudahkan guru dalam menyampaikan materi ajar dengan harapan siswa tersebut dapat menguasai materi yang diajarkan (Masturah, 2018). Pemanfaatan media pembelajaran dalam proses pembelajaran mampu membuat siswa lebih fokus karena ada objek yang dapat dijadikan titik fokus selain guru di kelas. Penggunaan media membuat kegiatan pembelajaran menjadi lebih bervariasi dan tidak terkesan menoton, sehingga siswa menjadi tidak bosan. Dengan berbagai manfaat media dalam pembelajaran, sudah sewajarnya jika guru menggunakan media pembelajaran yang menyesuaikan dengan tujuan pembelajaran, gaya belajar siswa, kebutuhan belajar, dan materi pembelajaran (Ramayulis, 2018).

Media pembelajaran yang dikembangkan adalah kartu domino yang telah modifikasi. Media pembelajaran kartu domino merupakan media pembelajaran berbentuk kartu domino yang berisi pertanyaan dan jawaban terkait dengan topik hewan dan tumbuhan di lingkungan rumahku. Perpaduan unsur visual berupa gambar dan tulisan pada kartu domino dirancang sedemikian rupa agar dapat menarik perhatian siswa pada saat pembelajaran berlangsung (Baihaqi, 2018).

Menurut (Melina, 2017) kartu domino dimainkan oleh sekelompok orang dengan cara mencocokan kartu yang satu dengan kartu yang lain. Media pembelajaran kartu domino tersebut dapat dijadikan media pembelajaran yang menarik bagi siswa karena digunakan sambil bermain yang dapat menstimulus peserta didik untuk lebih aktif dalam pembelajaran, membuat peserta didik tidak mudah bosan, meningkatkan hasil belajar peserta didik, kerjasama, melatih daya ingat siswa, dan siswa juga akan saling berinteraksi dengan siswa lainnya. (Nurhamidin, 2018) menyatakan bahwa domino memiliki karakteristik yang sangat aplikatif, dintaranya: 1) ideal untuk materi yang hendak disampaikan, 2) dapat digunakan untuk mengetahui apa yang telah diketahui oleh siswa, 3) kegiatan ini menuntut semua orang untuk terlibat, 4) membantu siswa yang lebih pemalu menjadi lebih terbuka, 5) kedua sisi pada kartu domino dapat digunakan sebagai pertanyaan dan jawaban yang lebih komplek. Pernyataan para ahli juga diperkuat oleh hasil penelitian terkait yang didapatkan dan sesuai dengan hasil penelitian yang diharapkan peneliti diantaranya menurut (Setiawan, 2020) menyebutkan bahwa media kartu domino dapat digunakan sebagai media pembelajaran yang dapat menarik perhatian dan minat belajar peserta didik. Media kartu domino memiliki sifat yang mengoptimalkan belajar sambil bermain, sehingga peserta didik lebih semangat mengikuti pembelajaran. Tujuan penggunaan media pembelajaran kartu domino agar materi pembelajaran mudah diingat oleh siswa.

Oleh karena itu, penggunaan media dalam proses pembelajaran di sekolah dasar sangat penting. Mata pelajaran IPA membutuhkan media dalam pengajarannya dengan materi yang berhubungan dengan makhluk hidup seperti hewan, dan tumbuhtumbuhan. Kelebihan media kartu domino dengan media pembelajaran yang lainnya yaitu memiliki gambar-gambar dan warna yang menarik, gampang digunakan, media kartu domino menuntut semua siswa untuk terlibat, membantu siswa yang lebih pemalu menjadi lebih terbuka, kedua sisi pada kartu domino dapat digunakan sebagai pertanyaan dan jawaban yang lebih komplek, pertanyaan pada kartu domino dapat digunakan pada semua materi pelajaran dan mata pelajaran, media kartu domino dapat digunakan pada tingkat kelas yang berbeda dan membuat siswa lebih aktif karena memuat materi yang dikemas dalam bentuk permainan. Hal ini sesuai dengan karakteristik siswa sekolah dasar yang masih lekat dengan bermain. Belajar sambil bermain menggunakan kartu domino melibatkan siswa dalam belajar, bergerak, 
berkelompok serta dalam praktik penggunaannya. (Widiyasanti, \& Ayriza, 2018) menyatakan umumnya karakteristik anak sekolah dasar sangat menyenangi visual yang menarik dan intraktif, suka bermain, serta senang merasakan ataupun melakukan sesuatu secara langsung. Berdasarkan uraian tersebut maka penelitian ini mengambil judul "Pengembangan Media Kartu Domino Pada Pembelajaran IPA Dengan Topik Hewan dan Tumbuhan di Lingkungan Rumahku untuk Siswa Kelas IV SD".

\section{METODE}

Penelitian ini merupakan penelitian pengembangan yang dikenal dengan (R\&D) research and development dengan menggunakan model ADDIE. Pengembangan adalah cara ilmiah untuk meneliti, merancang, memproduksi dan menguji validitas produk yang telah dihasilkan (Sugiyono, 2017).

Model ADDIE memiliki lima tahap atau langkah, pengaplikasiannya harus secara sistematik. Tahap atau langkah ini lebih sederhana dibandingkan dengan model pengembangan yang lainnya. Sifatnya yang sederhana dan terstruktur dengan sistematis maka model ini mudah dipahami dan diaplikasikan (Suryani, 2018). Tahap model ADDIE meliputi analysis, design, development, implementation, evaluation. Analysis berkaitan dengan kegiatan analisis terhadap situasi kerja dan lingkungan sehingga dapat ditemukan produk apa yang perlu dikembangkan. Design merupakan kegiatan perancangan produk sesuai dengan yang dibutuhkan. Development adalah kegiatan pembuatan dan pengujian produk. Implementation adalah kegiatan menggunakan produk, dan Evaluation adalah kegiatan menilai apakah setiap langkah kegiatan dan produk yang telah dibuat sudah sesuai dengan spesifikasi atau belum (Sugiyono, 2016). Namun pada tahap Evaluation (evaluasi) pada penelitian ini tidak dilaksanakan karena penelitian hanya dilakukan pada uji coba terbatas.
Subjek uji coba produk dilakukan oleh 2 orang ahli. Ahli ini berperan dalam perolehan data mengenai validitas media kartu domino yang terdiri dari ahli isi mata pelajaran, dan ahli media pembelajaran. 1 orang guru, berperan dalam perolehan data mengenai kepraktisan media kartu domino. Subjek uji coba kelompok kecil adalah 12 orang siswa yang dipilih secara acak terdiri 4 orang siswa yang memiliki hasil belajar tinggi, 4 orang siswa yang memiliki hasil belajar sedang, 4 orang siswa yang memiliki hasil belajar rendah. Subjek uji coba lapangan menggunakan seluruh siswa dari kelas IV SD No. 2 Mengwitani yang berjumlah 18 orang siswa. Siswa-siswa dalam uji coba lapangan tersebut sudah termasuk siswa yang memiliki hasil belajar tinggi, hasil belajar sedang, dan hasil belajar rendah.

Pengumpulan data dalam penelitian pengembangan ini menggunakan metode observasi, wawancara, pencatatan dokumen, tes dan kuesioner. Observasi merupakan cara yang dilakukan untuk mendapatkan data melalui pengamatan secara langsung di lapangan (Agung, 2017).

Wawancara merupakan cara mendapatkan informasil melalui tanya jawab yang sistematis yang direkam atau dicatat secara cermat (Agung, 2017). Wawancara digunakan untuk mengumpulkan data mengenai masalah pembelajaran yang terjadi di lapangan.

Metode pencatatan dokumen merupakan cara mendapatkan data melalui pengumpulan berbagai jenis dokumen dan melakukan pencatatan secara sistematis (Agung, 2017).

Metode tes merupakan cara untuk mengetahui pengetahuan, keterampilan, intelegensi atau kemampuan yang dimiliki siswa dengan menggunakan pertanyaanpertanyaan berupa tes objektif. Tujuan dari metode tes untuk mengetahui efektivitas penggunaan media pembelajaran kartu domino terhadap peningkatnya hasil belajar IPA siswa kelas IV SD No. 2 Mengwitani. Metode ini digunakan pada tahap 
implementasi atau penerapan yang dilakukan dengan pretest dan posttest dalam bentuk soal pilihan ganda untuk mengukur hasil belajar siswa sebelum dan sesudah menggunakan media pembelajaran kartu domino.

Metode kuesioner dilakukan dengan memberikan instrumen berupa daftar pertanyaan yang harus dijawab oleh orang yang menjadi subjek dalam penelitian (Lestari \& Yudhanegara, 2017). Metode kuesioner digunakan untuk mengetahui karakteristik siswa, mengukur kelayakan produk yang dikembangkan dari ahli isi mata pelajran, ahli media pembelajaran, uji coba kelompok kecil dan uji coba lapangan. Adapun kisi-kisi instrumen dalam penelitian ini dapat disajikan pada tabel berikut.

Tabel 1. Kisi-kisi Instrumen Ahli Isi Pelajaran

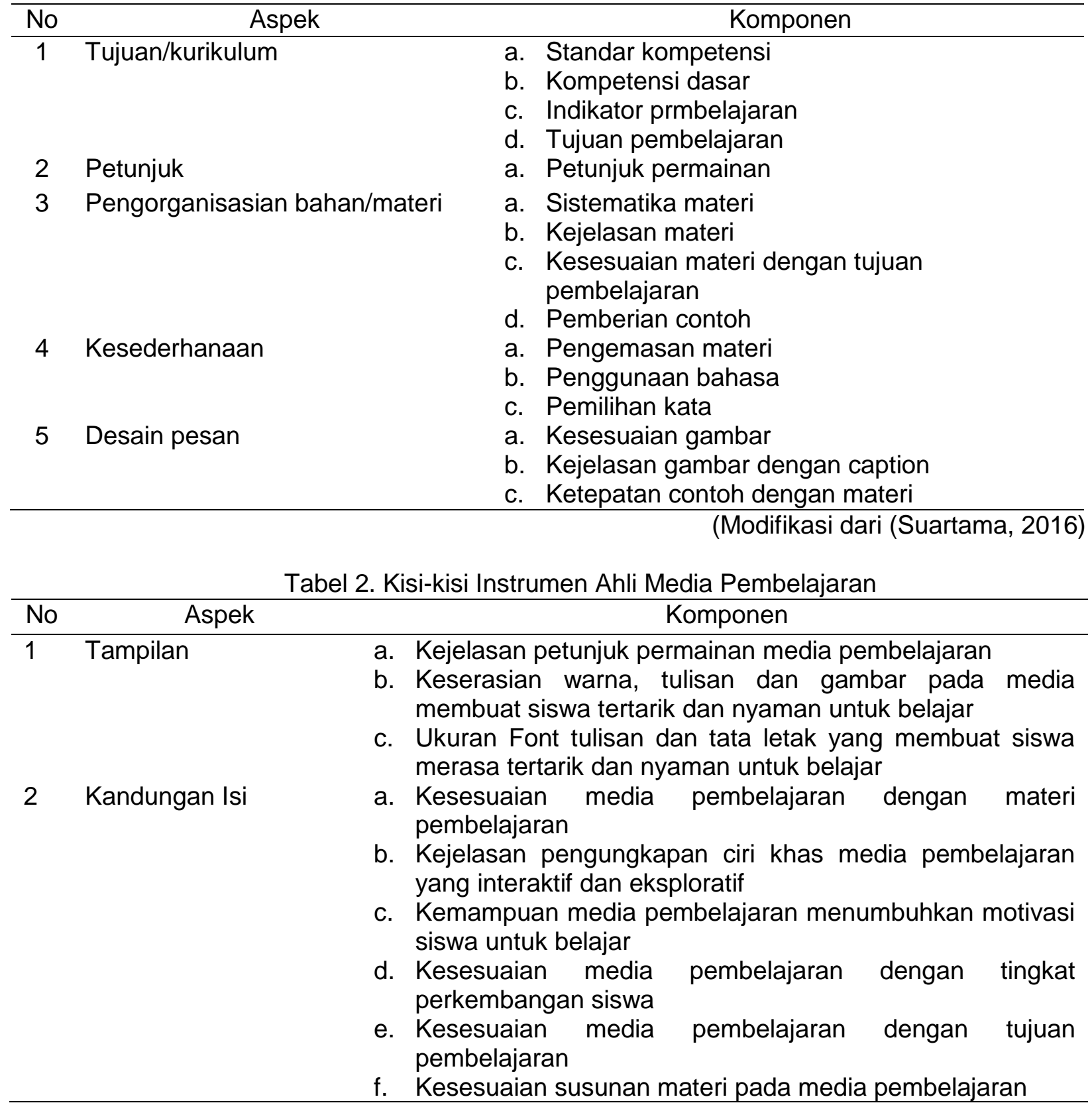




\begin{tabular}{|c|c|c|}
\hline No & Aspek & Komponen \\
\hline 3 & Daya Dukung & $\begin{array}{l}\text { a. Dukungan media pembelajaran terhadap kreativitas siswa } \\
\text { dalam belajar }\end{array}$ \\
\hline 4 & Penggunaan & $\begin{array}{l}\text { a. Kemudahan Penggunaan Media pembelajaran } \\
\text { b. Kemudahan dipahaminya petunjuk - petunjuk pada media } \\
\text { pembelajaran }\end{array}$ \\
\hline 5 & Penggunaan Bahasa & $\begin{array}{l}\text { a. Kesesuaian Bahasa Indonesia yang digunakan dengan } \\
\text { EYD } \\
\text { b. Kejelasan makna kalimat }\end{array}$ \\
\hline
\end{tabular}

Tabel 3.Kisi-Kisi Instrumen Uji Coba Kelompok Kecil, dan Lapangan

\begin{tabular}{|c|c|c|}
\hline No & Aspek & Komponen \\
\hline \multirow[t]{3}{*}{1} & Teks & a. Ukuran teks \\
\hline & & b. Jenis teks \\
\hline & & c. Warna teks \\
\hline \multirow[t]{4}{*}{2} & Ilustrasi & a. Pemilihan gambar \\
\hline & & b. Ukuran gambar \\
\hline & & c. Warna gambar \\
\hline & & d. Peletakkan gambar \\
\hline \multirow[t]{2}{*}{3} & Tampilan & a. Kemenarikan tampilan fisik \\
\hline & & b. Memotivasi siswa \\
\hline \multirow[t]{3}{*}{4} & Aksebilitas & a. Kemudahan menggunakan media \\
\hline & & b. Kejelasan petunjuk penggunaan \\
\hline & & c. Ketahanan media ketika digunakan (tidak mudah rusak) \\
\hline
\end{tabular}

Tabel 4. Kisi-Kisi Instrumen Respon Guru dan Siswa

\begin{tabular}{|c|c|c|}
\hline No & Aspek & Komponen \\
\hline 1 & Tampilan & $\begin{array}{l}\text { a. Tampilan media pembelajaran menarik } \\
\text { b. Teks/tulisan dapat dibaca dengan jelas } \\
\text { c. Bahasa yang digunakan mudah dipahami } \\
\text { d. Komposisi warna }\end{array}$ \\
\hline 2 & KemudahanPenggunaan & a. Guru dapat menggunakan media secara mandiri \\
\hline 3 & PenyajianMateri & $\begin{array}{l}\text { a. Materi yang disajikan mudah ipahami } \\
\text { b. Visual yang disajikan menambah pemahaman materi } \\
\text { c. Permainan kartu domino mudah dipahami }\end{array}$ \\
\hline 4 & Manfaat & $\begin{array}{l}\text { a. Media pembelajaran menumbuhkan semangat dalam } \\
\text { mengajar } \\
\text { b. Media pembelajaran kartu domino dapat diterapkan } \\
\text { untuk materi IPA lainnya } \\
\text { c. Kerjasama dalam kelompok }\end{array}$ \\
\hline
\end{tabular}

Metode analisis data yang digunakan dalam penelitian pengembangan ini yaitu metode analisis deskriptif kualitatif dan metode analisis deskriptif kuantitatif. Metode analisis kualitatif merupakan suatu cara untuk menganalisis data yang dilakukan dengan sistematis dalam bentuk kalimat/kata-kata, kategori tentang objek (benda, gejala, dan variabel tertentu) sehingga mendapatkan kesimpulan umum 


$$
\bar{x}=\frac{\sum x}{n}
$$

(Agung, 2017). Metode analisis kualitatif ini uji ahli isi mata pembelajaran, ahli media pembelajaran, uji coba kelompok kecil dan uji coba lapangan. Data yang didapatkan kemudian dikelompokkan berdasarkan masukan, kritik, tanggapan, dan saran yang terdapat pada kuesioner.

Metode analisis deskriptif kuantitatif merupakan suatu cara pengolahan data yang dilakukan dengan cara menyusun secara sistematis dalam bentuk angkaangka dan atau presentasi mengenai suatu objek yang diteliti, sehingga mendapatkan kesimpulan (Agung, 2017).

Validitas dari media kartu domino ini dapat diketahui dari data angket mengenai tanggapan ahli terkait kelayakan/kevalidan media kartu domino yang dianalisis dengan rumus berikut.

Persentase $=(F: N) \times 100 \%$ (Tegeh \& Jampel, 2017)

Keterangan:

$\mathrm{F}=$ jumlah persentase keseluruhan subyek $\mathrm{N}$ = banyak subyek

Untuk dapat memberikan makna dan pengambilan keputusan digunakan tabel ketetapan sebagai berikut.

Tabel 5. Konversi Tingkat Pencapaian Dengan Skala 5

\begin{tabular}{|c|c|c|}
\hline $\begin{array}{c}\text { Tingkat } \\
\text { Pencapaian }\end{array}$ & Kualifikasi & Keterangan \\
\hline $90 \%-100 \%$ & Sangat baik & $\begin{array}{c}\text { Tidak perlu } \\
\text { direvisi }\end{array}$ \\
\hline $75-74 \%$ & Baik & $\begin{array}{c}\text { Direvisi } \\
\text { seperlunya }\end{array}$ \\
\hline $65 \%-74 \%$ & Cukup & $\begin{array}{c}\text { Cukup } \\
\text { banyak revisi }\end{array}$ \\
\hline $55 \%-64 \%$ & Kurang & Banyak revisi \\
\hline $0-54 \%$ & $\begin{array}{l}\text { Sangat } \\
\text { kurang }\end{array}$ & Direvisi total \\
\hline
\end{tabular}

Kepraktisan media kartu domino yang dikembangkan dalam penelitian ini dapat diketahui dari data angket hasil respon siswa dan respon guru yang dianalisis dengan rumus:
Keterangan:

(Sudijono, 2010)

$\bar{x} \quad$ : rata-rata skor

$\sum \mathrm{x} \quad$ : jumlah skor

n : jumlah item pernyataan

Tabel 6. Kriteria Kepraktisan Media Kartu Domino

\begin{tabular}{cc}
\hline $\begin{array}{c}\text { Rentangan Kategori } \\
\text { Skor }\end{array}$ & Kriteria \\
\hline $4,20 \leq x \leq 5,00$ & Sangat Tinggi \\
$3,40 \leq x \leq 4,19$ & Tinggi \\
$2,60 \leq x \leq 3,39$ & Sedang \\
$1,80 \leq x \leq 2,59$ & Rendah \\
$1,00 \leq x \leq 1,79$ & Sangat Rendah \\
\hline \multicolumn{2}{c}{ (Muhidin \& Maman, 2007) }
\end{tabular}

Pada penelitian ini menggunakan uji beda yaitu uji-t dari hasil pretest dan posttest antara pembelajaran sebelum menggunakan media kartu domino dan pembelajaran sesudah menggunakan media kartu domino. Sebelum melakukan uji hipotesis (uji-t), perlu dilakukan uji prasyarat analisis data yang meliputi uji normalitas dan uji homogenitas. Uji normalitas dilakukan untuk menyampaikan sampel benar-benar berasal dari populasi yang berkontrubusi normal. Uji normalitas untuk skor hasil belajar digunakan analisis ChiKuadrat dengan rumus.

$$
x^{2}=\sum \frac{(f o-f e)^{2}}{f e}
$$

(Koyan, 2012)

Keterangan :

$$
x^{2}=\text { chi-Kuadrat }
$$

fo $=$ frekuensi observasi

$f e$ frekuensi harapan

Kriteria pengujian dapat berdistribusi normal jika $X^{2}$ hit $\leq X^{2}$ tab, dengan taraf signifikansi $5 \%$ dan derajat kebebasan $\mathrm{dk}=$ $(\mathrm{n}-1)$. Uji homogenitas varians dalam penelitian pengembangan ini dilakukan untuk mencari bahwa dua atau lebih kelompok data sampel berasal dari populasi yang memiliki varians yang sama. Uji 
homogenitas varians untuk kedua kelompok digunakan dengan rumus berikut.

$$
F_{\text {hit }}=\frac{\text { Varians terbesar }}{\text { Varians terkecil }}
$$

(Koyan, 2012)

Kriteria pengujian tolak Ho jika Fhit $\geq$ Ftabel (n1-1,n2-1), yang berarti sampel tidak homogen sedangkan tolak $\mathrm{H} 1$ jika $\mathrm{F}$ hitung $\leq$ Ftabel (n1-1,n2-1) yang berarti sampel homogen. Uji dilakukan pada taraf signifikan $5 \%$ dengan derajat kebebasan untuk pembilang $\mathrm{n} 1-1$ dan derajat kebebasan untuk penyebut n2-1.

Uji hipotesis yang dilakukan dalam penelitian ini menggunakan analisis uji-t, karena penelitian ini merupakan penelitian dengan membandingkan hasil pretest dan hasil posttest. Teknik analisis data yang digunakan untuk menguji hipotesis dalam penelitian ini, yaitu menggunakan analisis uji-t sampel berkolerasi, dengan rumus sebagai berikut.

$\mathrm{t}=\frac{\overline{x_{1}}-\overline{\bar{x}_{2}}}{\sqrt{\frac{s_{1}^{2} s^{2}}{n_{2}}+\frac{2}{n_{2}}-2 r\left(\frac{s 1}{\sqrt{n 1}}\right)\left(\frac{s_{2}}{\sqrt{n_{2}}}\right)}}$

(Koyan, 2012)

Keterangan

$\overline{x_{1}}=$ rata-rata sampel 1

$\overline{x_{2}}=$ rata-rata sampel 2

$s_{1}=$ simpangan baku sampel

$s_{2}=$ simpangan baku sampel

$s_{1}^{2}=$ varians sampel

$s_{2}^{2}=$ varians sampel 2

Dengan kriteria jika harga $t_{\text {hitung }}$ lebih kecil dari $t_{\text {tabel }}$, maka gagal menolak Ho, dan jika $t_{\text {hitung }}$ lebih besar dari harga $t_{\text {habel }}$, maka $\mathrm{H} 1$ diterima.

\section{HASIL DAN PEMBAHASAN}

Hasil dan pembahasan pada penelitian ini, secara detail dapat dipaparkan sebagai berikut:

Hasil

Hasil penelitian ini berupa media kartu domino pada pembelajaran IPA dengan topik hewan dan tumbuhan di lingkungan rumahku kelas IV SD. Proses pengembangan media kartu domino pada penelitian ini menggunakan model ADDIE. Tahap pertama yang dilakukan yaitu tahap analisis (analyze). Pada tahap ini dilakukan analisis kebutuhan meliputi penyebaran kuesioner pada guru dan siswa kelas IV SD No.2 Mengwitani. Hasil penyebaran kuesioner yang dilakukan terhadap siswa dan guru menyatakan bahwa materi pembelajaran pada buku siswa kurang luas. Siswa dan guru setuju jika materi IPA dikembangkan dalam bentuk media. Analisis karakteristik siswa di SD No. 2 Mengwitani merupakan siswa yang jarang menggunakan media pembelajaran mereka lebih menyukai bermain saat belajar. Siswa juga memiliki karakteristik yang mudah bosan dan memiliki ketertarikan terhadap media yang menarik dengan warna. Analisis kurikulum dilaksanakan dalam menganalisis $\mathrm{KI}$ (kompetensi inti), KD (Kompetensi dasar), indikator pencapaian kompetensi, dan tujuan pembelajaran sebagai dasar untuk membuat media kartu domino. Kompetensi dasar yang dianalisis selanjutnya dirinci dan dijabarkan menjadi beberapa indikator pencapaian kompetensi yang menjadi acuan dalam mengembangkan media kartu domino pada topik hewan dan tumbuhan di lingkungan rumahku.

Tahap kedua perancangan (Design). Adapun perancangan media kartu domino yang tahapannya dimulai dari pembuatan desain kartu domino, pemilihan warna untuk latar kartu domino, pemilihan gambar, pemilihan jenis tulisan dan ukuran huruf yang digunakan. Kartu domino ini didesain menggunakan photoshoope yaitu membuat kotak ukuran $8 \times 5 \mathrm{~cm}$, kotak kartu tersebut diberi pembatas pada bagian tengahnya. Kartu domino yang dibuat berjumlah 20 kartu.

Tahap ketiga pengembangan (development) pada tahap ini kegiatan yang dilakukanyaitu mengembangkan produk berupa media kartu domino dari wujud desain menjadi produk yang sesungguhnya. Adapun uraian dari tahap produksi untuk 
menghasilkan produk, yaitu menggunakan aplikasi yang sudah dipilih sebelumnya untuk membuat media kartu domino, pemilihan gambar, warna dan tulisan, memasukkan materi beserta gambar pendukung lainnya dan terakhir pencetakan kartu domino.

Tahap keempat implementasi (implementation) media kartu domino yang telah melewati proses perbaikan dan dinyatakan layak untuk digunakan, kemudia dilakukan penerapan pada situasi yang nyata yaitu proses pembelajaran di SD No. 2 Mengwitani. Pada tahap implementasi kegiatan yang dilakukan yaitu uji validitas produk oleh para ahli diantaranya, ahli isi mata pelajaran, ahli media pembelajaran, uji coba produk yang meliputi uji coba kelompok kecil dan uji coba lapangan.

Hasil validitas media kartu domino ditentukan berdasarkan hasil review ahli isi mata pembelajaran, ahli ahli media pembelajaran, uji coba kelompok kecil dan uji coba lapangan. Adapun hasil uji validitas dari pengembangan media kartu domino menurut para ahli dan uji coba produk dapat disajikan pada tabel.

Tabel 7. Hasil Validitas Media Kartu Domino

\begin{tabular}{clcc}
\hline No & $\begin{array}{c}\text { Subjek Uji } \\
\text { Coba Media } \\
\text { Kartu Domino }\end{array}$ & $\begin{array}{c}\text { Hasil } \\
\text { Validitas } \\
(\%)\end{array}$ & Kriteria \\
\hline 1 & $\begin{array}{l}\text { Uji Ahli Isi } \\
\text { Mata }\end{array}$ & $92 \%$ & $\begin{array}{c}\text { Sangat } \\
\text { Baik }\end{array}$ \\
& $\begin{array}{l}\text { Pelajaran } \\
\text { Uji Ahli Media }\end{array}$ & $90 \%$ & $\begin{array}{c}\text { Sangat } \\
\text { Baik }\end{array}$ \\
& $\begin{array}{l}\text { Pembelajaran } \\
\text { Uji Coba }\end{array}$ & $92 \%$ & $\begin{array}{c}\text { Sangat } \\
\text { Baik }\end{array}$ \\
& $\begin{array}{l}\text { Kelompok } \\
\text { Kecil Coba } \\
4 j i \quad 93 \% \\
\text { Lapangan }\end{array}$ & $\begin{array}{c}\text { Sangat } \\
\text { Baik }\end{array}$ \\
\hline
\end{tabular}

Berdasarkan hasil perolehan data tersebut, dapat disimpulkan bahwa media kartu domino memiliki validitas sangat baik dan layak digunakan untuk membantu siswa meningkatkan hasil belajar pada pembelajaran IPA serta mempermudah guru dalam menyampaikan materi pembelajaran. Melalui hasil uji validitas produk diperoleh masukan, saran, dan komentar yang diberikan oleh para ahli dan subjek uji coba produk. Masukan, saran, dan komentar tersebut selanjutnya dijadikan sebagai dasar atau acuan dalam melakukan perbaikan/revisi produk demi kesempurnaan produk yang dihasilkan. Adapun hasil pengembangan media kartu domino dapat disajikan sebagai berikut.

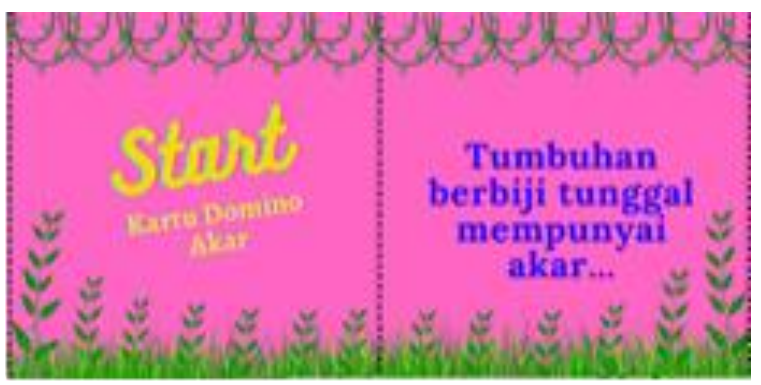

Gambar 1. Kartu Domino Akar

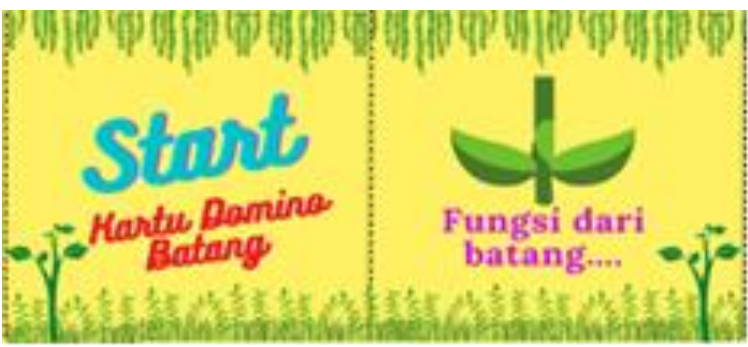

Gambar 2. Kartu Domino Batang

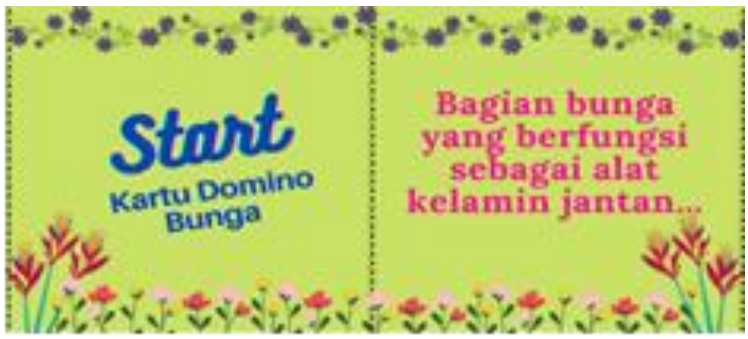

Gambar 3. Kartu Domino Bunga

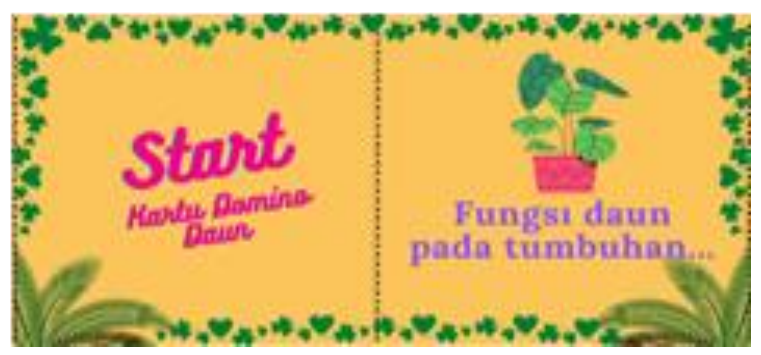

Gambar 4. Kartu Domino Daun 
Setelah dilakukan revisi berdasarkan masukan dari para ahli, maka tahap selanjutnya yaitu uji coba pada guru dan siswa untuk mengukur kepraktisan media kartu domino. Data kepraktisan diperoleh melalui angket yang diisi oleh orang guru dan siswa. Adapun hasil analisis kepraktisan respon guru dan siswa yaitu sebagai berikut.

Tabel 8. Hasil Kepraktisan Media Kartu Domino

\begin{tabular}{ccc}
\hline $\begin{array}{c}\text { Rata-rata Skor } \\
\text { Respon Guru }\end{array}$ & $\begin{array}{c}\text { Rata-rata Skor } \\
\text { Respon Siswa }\end{array}$ & Kriteria \\
\hline 4,53 & 4,56 & $\begin{array}{c}\text { Sangat } \\
\text { tinggi }\end{array}$ \\
\hline
\end{tabular}

Efektivitas penggunaan produk media kartu domino sebelum menerapkan media kartu domino pada mata pelajaran IPA, peneliti melakukan tes awal (pretest) terhadap siswa kelas kelas IV SD No. 2 Mengwitani. Selanjutnya dilakukan tes akhir (posttest). Uji normalitas dilakukan untuk mengetahui apakah sebaran skor pada setiap variabel berdistribusi normal atau tidak.

Tabel 9. Hasil Uji Normalitas Pretest dan Posttest

\begin{tabular}{crcc}
\hline $\begin{array}{c}\text { Kelompok } \\
\text { data }\end{array}$ & $x^{2}{ }_{\text {hitung }}$ & $x^{2}$ tabel & Status \\
\hline Pretest & 1,061 & 11,070 & Normal \\
Posttest & 1,588 & 11,070 & Normal \\
\hline
\end{tabular}

Berdasarkan tabel terlihat bahwa hasil perhitungan chi kuadrat, diperoleh $x^{2}$ hitung < $x^{2}{ }_{\text {tabel }}$ dengan taraf signifikansi $5 \%$. Dengan demikian semua data skor hasil belajar IPA siswa berdistribusi normal. Uji homogenitas ini dilakukan untuk mengetahui apakah sampel yang digunakan uji validasi produk memiliki data yang homogen atau sama dengan sampel yang akan digunakan untuk uji efektivitas. Uji homogenitas dilakukan pada kelas IV sebagai sampel uji efektivitas produk. Berdasarkan hasil pengujian diperoleh $\quad F_{\text {hitung }} \leq F_{\text {tabel }} \quad$ yaitu: $F_{\text {hitung }}(1,08) \leq F_{\text {tabel }}(4,54)$ sehingga $H_{1}$ ditolak yang berarti sampel bersifat homogen.

Pengujian hipotesis penelitian dilakukan dengan analisis uji-t berkolerasi. Semua pengujian hipotesis dilakukan pada taraf signifikan 5\%. Selanjutnya harga $t$ hitung dibandingkan dengan harga $t$ pada tabel dengan $\mathrm{db}=\mathrm{n} 1+\mathrm{n} 2-2=18+18-2=34$. Harga t tabel untuk db 34 dan dengan taraf signifikansi 5\% $(\alpha=0,05)$ adalah 1,684. Dengan demikian, harga t hitung lebih besar dari pada harga t tabel, sehingga Ho ditolak dan $\mathrm{H} 1$ diterima. Ini berarti terdapat perbedaan yang signifikan hasil belajar IPA siswa antara sebelum dan sesudah menggunakan media kartu domino.

\section{Pembahasan}

Media kartu domino yang dikembangkan dalam penelitian ini bertujuan agar siswa dapat meningkatkan hasil belajar, memudahkan siswa menerima materi pelajaran, mempermudah guru dalam mengembangkan kegiatan pembelajaran serta mengelola kelas. Hasil penelitian ini menunjukkan bahwa media kartu domino yang dikembangkan telah melalui serangkaian tahap pengembangan dan telah divalidasi oleh para ahli dibidangnya masing-masing serta telah diuji cobakan.

Model ADDIE ini digunakan karna prosedur dan langkah-langkah yang dilalui dalam pengembangan produk ini sangat mudah dan jelas serta sistematis sehingga sesuai dengan desain pembelajaran yang dikembangkan. Hal ini sejalan dengan pendapat ahli dari (Tegeh \& Kirna, 2013) menyatakan bahwa model ADDIE merupakan model desain pembelajaran yang paling generik dan dikembangkan dengan secara sistematis serta berpijak pada landasan teoritis pada desain pembelajaran. Pertimbangan yang harus di perhatikan dalam menentukan model pengembangan yang akan digunakan dalam proses pemebuatan produk diantarnya adalah: (1) model yang dipilih haruslah dipahami oleh pengembang, (2) tahapan mengandung yang tidak perlu 
kompleks juga tidak terlalu sederhana, dan (3) model dapat mengarahkan pengembang membuat program secara lebih aktif (Mahadewi \& Sukmana, 2015).

Hasil review ahli isi pelajaran, menunjukkan bahwa media kartu domino memperoleh kualifikasi sangat baik yaitu $92 \%$. Kualifikasi sangat baik ini diperoleh karena pada review ahli isi pembelajaran terhadap butir instrumen kesesuaian kompetensi dasar atau tujuan pembelajaran berada pada validitas sangat tinggi yaitu dengan tingkat pencapaian 1,00. Hal ini sejalan dengan pernyataan (Mubin, 2018) yang menjelaskan bahwa tujuan pembelajaran menggambarkan proses dan hasil belajar yang dicapai secara optimal oleh siswa sesuai dengan kompetensi serta indikator pembelajaran. Tujuan pembelajaran dijadikan sebagai acuan untuk memaksimalkan pembelajaran sehingga dapat mencapai tujuan pembelajaran yang diinginkan. Dengan demikian dapat dikatakan bahwa semakin baik tingkat kesesuaian materi pembelajaran dengan tujuan pembelajaran, maupun tujuan pembelajaran dengan indikator maka akan dapat mengarahkan kegiatan pembelajaran kearah yang optimal.

Dari hasil review ahli media pembelajaran, yakni 90\% dengan kualifikasi sangat baik. Kualifikasi sangat baik ini diperoleh pada butir instrumen tentang keseimbangan antara teks dan gambar yang mendukung, kejelasan petunjuk permainan, tampilan, gambar, warna, dan materi. Menurut (Sudatha \& Tegeh, 2009) mengenai penggunaaan teks yang baik dalam pembuatan sebuah media pembelajaran yaitu bahwa huruf yang digunakan harus kecil dan mudah dibaca. Gambar yang digunakan dalam pembuatan media kartu domino menggunakan gambar yang sederhana dan sering ditemui oleh siswa di lingkungannya.

Validasi dalam uji coba kelompok kecil memperoleh persentase sebesar 92\% dengan kualifikasi sangat baik dan uji coba lapangan memperoleh $93 \%$ dengan kualifikasi sangat baik. Tercapainya dari semua uji coba tersebut, dikarenakan media kartu domino ini sangat mudah digunakan oleh siswa serta gambar dalam media kartu domino sangat menarik perhatian siswa. Dengan pemilihan gambar yang menarik siswa dapat terfokus ke media dan pembelajaran. Sejalan dengan pendapat ahli (Sudarma, 2015) menyatakan bahwa gambar merupakan representasi konkret dari pesan yang disajikan dengan kata-kata. Pesan yang disajikan melalui gambar akan sangat membantu siswa menginterprestasikan pesan.

Kepraktisan media kartu domino ini diperoleh dari hasil analisis angket respon siswa memperoleh rata-rata skor kepraktisan sebesar 4,56 dengan kategori sangat tinggi dan respon guru terhadap media kartu domino memperoleh rata-rata skor sebesar 4,53 dengan kategori sangat tinggi ini diperoleh karena kemudahan penggunaan media dan media digunakan dengan cara bermain yang membuat anakanak sangat antusias untuk belajar. Hal ini sejalan dengan pendapat (Nugraheni, 2017) menyatakan bahwa media permainan dapat membantu dalam peningkatan kualitas pembelajaran IPA di sekolah dasar. Media permainan menginspirasi siswa untuk meningkatkan ketrampilan mereka dengan perasaan senang. Perasaan senang ini mendorong siswa untuk terus berlatih. Menurut (Prasetya \& Hakim, 2017) menjelaskan bahwa media yang baik harus memenuhi syarat pertimbangan kepraktisan sehingga mudah untuk digunakan. Berdasakan hal tersebut dapat disimpulkan bahwa media kartu domino dinyatakan praktis untuk digunakan.

Selain itu, penilaian yang diperoleh dari uji efektivitas media kartu domino hasilnya menunjukkan bahwa nilai rata-rata pretest adalah 53,52 sedangkan untuk ratarata posttest adalah 83,69. Hal ini berarti bahwa nilai rata-rata hasil belajar siswa sebelum dan sesudah menggunakan media kartu domino tidak sama, sehingga dapat disimpulkan bahwa terdapat perbedaan nilai 
rata-rata hasil belajar siswa sebelum menggunakan media kartu domino dengan sesudah menggunakan media kartu domino.

\section{PENUTUP}

Berdasarkan rumusan masalah, hasil analisis data dan pembahasan penelitian ini, maka dapat diambil kesimpulan sebagai berikut.

Kualitas media kartu domino pada pembelajaran IPA berdasarkan hasil evaluasi para ahli dan uji coba produk kepada siswa menunjukkan riview ahli isi mata pelajaran berada pada kualitas sangat baik dengan persentase $92 \%$, riview ahli media pembelajaran berada pada kualitas sangat baik dengan persentase $90 \%$. Pada uji coba kelompok kecil berada pada kualitas sangat baik dengan persentase $92 \%$, dan uji coba lapangan berada pada kualitas sangat baik dengan persentase 93\%. Media kartu domino telah diuji kepraktisannya yaitu respon siswa dan respon guru. Kepraktisan media kartu domino ini dinilai berdasarkan hasil penilaian angket respon siswa dari 18 orang siswa dan angket respon guru. Hasil analisis angket respon siswa memiliki rata-rata skor keseluruhan 4,56 yang artinya memiliki tingkat kepraktisan tinggi. Hasil analisis angket respon guru memperoleh rata-rata 4,53 yang berarti memiliki tingkat kepraktisan sangat tinggi.

Pengembangan media kartu domino pada pembelajaran IPA kelas IV efektif, karena rata-rata nilai pretest adalah 53,52 dan rata-rata nilai posttest adalah 83,69. Setelah dilakukan penghitungan secara manual diperoleh hasil $\mathrm{t}$ hitung sebesar 85,05 kemudian harga $t$ hitung dibandingkan dengan harga $t$ pada tabel dengan $\mathrm{db}=\mathrm{n} 1+\mathrm{n} 2-2=18+18-2=34$. Harga t tabel untuk db 34 dan dengan taraf signifikansi $5 \%(\alpha=0,05)$ adalah 1,684. Dengan demikian, harga t hitung lebih besar dari pada harga t tabel sehingga Ho ditolak dan $\mathrm{H} 1$ diterima. Ini berarti, terdapat perbedaan yang signifikan hasil belajar IPA siswa antara sebelum dan sesudah menggunakan media kartu domino.
Berdasarkan hasil penelitian dan pembahasan terhadap media kartu domino dapat diajukan beberapa saran yang diantaranya untuk para siswa diharapkan dapat menggunakan media kartu domino mengembangkan kemampuannya untuk menambah pengetahuan dan wawasan terhadap peningkatan hasil belajar.

Kepada guru sebaiknya lebih inovatif dan bisa memilih media-media yang menarik dalam pembelajaran. Hal tersebut dilakukan sehingga pembelajaran dikelas bisa beragam dan menjadi menyenangkan serta dapat memotivasi peserta didik untuk belajar.

Sekolah diharapkan dapat menyediakan sarana dan prasarana pembelajaran yang diperlukan, sehingga pembelajaran dapat berlangsung secara optimal.

\section{DAFTAR PUSTAKA}

Agung, A. A. G. (2017). Metodologi Penelitian Kuantitatif (Prespektif Manajemen Pendidikan). https://media.neliti.com/media/publicat ions/331356-analisis perkembanganfisik-motorik-sisw-204349ba.pdf.

Baihaqi, M. . (2018). Pengembangan Media Kartu Nusantara untuk Pembelajaran IPS Kelas IV SDN pada materi Keanekaragaman Suku Bangsa dan Budaya. Jurnal Ilmiah Pendidikan Guru Sekolah Dasar, 5(2).https://ejournal.upi.edu/index.php/ pedadidaktika/article/view/7353

Ibdal, F. (2015). Perkembangan Kognitif: Teori Jean Piaget. Jurnal Intelektualita, 3(1). https://jurnal.arraniry.ac.id/index.php/intel/article/view/ 197

Istiqomah, F., \& Widiyatmoka, A. (2016). Pengaruh Media Kokami terhadap Keterampilan Berpikir Kreatif dan 
Aktivitas Belajar Tema Bahan Kimia. Jurnal Unnes Science Education, 5(2).https://journal.unnes.ac.id/sju/ind ex.php/usej/article/view/11913

Koyan, I. W. (2012). Statistik Pendidikan: Teknik Analisis Data Kualitatif. Universitas Pendidikan Ganesha.

Kusnadi. (2017). Model Inovasi Pendidikan Dengan Strategi Implementasi Konsep "Dare To Be Different. Jurnal Wahana Pendidikan, 4(1), 132-144.

Lestari, E. \& Yudhanegara, M. R. (2017). Penelitian Pendidikan Matematika. Refika Aditama.

Mahadewi, L. P. P., \& Sukmana, A. I. W. I. Y. (2015). Text-Based Programming: Konsep Dasar \& Aplikasi Pengembangan Produk Pendidikan. Graha IImu.

Masturah, E. D. (2018). Pengembangan Media Pembelajaran Pop-Up Book Pada Mata Pelajaran IPA Kelas III Sekolah Dasar. Jurnal Universitas Pendidikan Ganesha, 6(2), 212-221. https://ejournal.undiksha.ac.id/index.p hp/JEU/article/view/20294

Melina, V. (2017). Pengembangan Donat Konservasi untuk Mningkatkan Hasil Belajar Kognitif Siswa IV SDN Purwoyoso01. Universitas Negeri Semarang.

Mubin, H. (2018). Analisis Kompetensi Guru Dalam Merencanakan dan Melaksanakan Pembelajaran Kimia Bernasis Kurikulum 2013 Studi Kasus di Kelas X SMA Negeri Pontianak. Jurnal IImiah, 6(2). http://openjurnal.unmuhpnk.ac.id/inde x.php/ar-r/article/view/1223.

Muhidin, S. A \& Maman, A. (2007). Analisis
Korelasi, Regresi dan Jalur dalam Penelitian. Pustaka Setia.

Mulyawati, I., \& Kowiyah, K. (2018). Pembelajaran Matematika dan IPA Guru SD Melalui Media Pembelajaran Visual. Jurnal SOLMA, 7(2), 247. https://doi.org/10.29405/solma.v7i2.16 52

Nugraheni, N. (2017). Implikasi Permainan Pada Pembelajaran Matematika di Sekolah Dasar. Jurnal Of Mathematics Education IKIP Veteran Semarang, 1(2). http://ejournal.ivet.ac.id/index.php/matematik a/article/view/490

Nurhamidin, F. (2018). Penggunaan Media Kartu Domino untuk Penguatan Kemampuan Faktual Siswa pada Mata Pelajaran Sejarah. Jurnal Pendidikan Sejarah, 6(4). https://jurnalfkip.unram.ac.id/index.php /JPM/article/view/2539

Permendiknas. (2006). Permendiknas No 22 Tahun 2006 Tentang Standar Isi. Depdiknas.

Prasetya, B. N \& Hakim, L. (2017). Pengembangan Permainan Kartu Domino sebagai Media Pengayaan Pada Materi Sistem Penilaian Persediaan. Jurnal Pendidikan. Jurnal Pendidikan, 5(4). https://ejournal.unesa.ac.id/index.php/j pak/article/view/17992/16398

Prastowo, A. (2013). Pengembangan Bahan Ajar Tematik. Divapress.

Ramayulis. (2018). Pengembangan Media Gambar untuk Meningkatkan Minat Belajar PKn Siswa Kelas II SD Negeri 127 Pekanbaru. Jurnal PAJAR (Pendidikan Dan Pengajaran) 
Program Studi Pendidikan Guru Sekolah Dasar FKIP Universitas Riau, 2(2).

https://pajar.ejournal.unri.ac.id/index.p $\mathrm{hp} / \mathrm{PJR}$

Sari, D. K. (2017). Meningkatkan Hasil Belajar IPA Melalui Model Pembelajaran Picture and Picture dan Think Pair Share (TPS). Jurnal Mitra Pendidikan, $1(5)$. https://ejurnalmitrapendidikan.com/ind ex.php/ejmp/article/view/107

Setiawan, Y. U. (2020). Pengembangan Kartu Domino Pecahan Sebagai Media Pembelajaran Matematika Dikelas IV Sekolah Dasar. Jurnal Keilmuan Dan Kependidikan Dasar, 12(1), $1-12$. http://jurnal.uinbanten.ac.id/index.php/ primary/article/view/2706/1930

Suartama, I. K. (2016). Evaluasi dan Kriteria Kualitas. Universitas Pendidikan Ganesha.

Sudarma. I K. (2015). Desain Oesan: Kajian Analisis Desain Visual (Teks dan Image). Graha IImu.

Sudatha, I G. W. \& Tegeh, I. M. (2009). Desain Multimedia Pembelajaran. Undiksha.

Sudijono. (2010). Pengantar Statistik Pendidikan. Raja Grafindo perkasa.

Sudradjat, H. (2005). Manajemen Peningkatan Mutu Berbasis Sekolah. Cipta Cekas Grafika.

Sugiyono. (2016). Metode Penelitian dan Pengembangan. Alfabeta.

Sugiyono, S. (2017). Metode Penelitian \& Pengembangan (3rd ed.). Alfabeta.

Suryani, N. (2018). Media Pembelajaran
Inovatif dan Pengembangannya. Remaja Rosdakarya.

Syahrul, R. M. (2019). Skor PISA Indonesia Merosot.

https://www.medcom.id/pendidikan/ne ws-pendidikan/GNIYly9bskor-pisaindonesia-merosot.

Tegeh, I. M., \& Jampel, I. N. (2017). Metode Penelitian Pengembangan. Undiksha.

Tegeh, I. M., \& Kirna, I. M. (2013). Pengembangan Bahan Ajar Metode Penelitian Pendidikan Dengan Addie Model. Jurnal Ika, 11(1), 12-26. https://ejournal.undiksha.ac.id/index.p hp/IKA/article/view/1145

Undang-Undang Republik Indonesia Nomor 20 Tahun 2003 Tentang Sistem Pendidikan Nasional. (n.d.).

Widiyasanti, M., \& Ayriza, Y. (2018). Pengembangan Media Video Animasi untuk Meningkatkan Motivasi Belajar dan Karakter Tanggung Jawab Siswa Kelas V. Jurnal Pendidikan Karakter, 6(1).https://doi.org/https://doi.org/10.2 1831/jpk.v8i1.21489. 